\title{
建築生産情報の確定過程に関する研究 \\ STUDY ON WORKING DRAWINGS AND SHOP DRAWINGS SCHEDULING
}

\author{
勝 山典 一*1，古阪秀三*2，藤 澤 克 樹*3，金多 隆*4 \\ Norikazu KATSUYAMA, Shuzo FURUSAKA, Katsuki FUJISAWA \\ and Takashi KANETA
}

The objectives that this paper has aimed at are as follows:

1) To develop a system which can quantitatively indicate the influence on the project cost by focusing on the finish time of working drawings and shop drawings.

2) To propose the method of optimizing the schedule of making working drawings and shop drawings under consideration of various constrained conditions.

Using this system, the owner of the project can get theoretical background for the adjustment of the conflict between the design team and the construction team from the point of the optimization of the project cost in the schedule of making working drawings and shop drawings. As local search is one of the most effective heuristic algorithms for optimization problem, it is applied to the optimization of the schedule of making working drawings and shop drawings.

Keywords : working drawings, shop drawings, scheduling, project cost, local search, optimization

\section{1. 序論}

\section{1 研究の背景と目的}

建筑プロジェクトには, 発注者, 設計者, 施工者などの複数の主 体が関係する。その中で, 生産に関する情報は, 各種の図面とそれ に付随する仕様書, 計算書などによって伝達される。建築生産情報 が確定される時には，設計内容の詳細な検討が行われている。

本研究は, それらの実態, 特にプロジェクトごとに行われてきた 経験的な工夫を把握した上で, (1)建築生産情報の確定工程を作成す ること, (2)建築生産情報確定工程の最適化方法を提案すること, (3) 実プロジェクトへ適用し有効性を確認すること，を目的とする。

\section{2 関連する既往研究と本研究の範囲・方法}

建築生産情報に関する既往研究として, 峰政らによる一連の先行 研究 ${ }^{6)}$ (10)があげられる。峰政らは, 建築生産情報の共有と整合の仕 組み, 情報の確定過程を明らかにした上で, 生産情報確定工程を構 築, 最適化する手法を提案している。しかし, 生産情報確定工程の 範囲を施工図，製作図の作成と検討・承認に限定しており，より川 上側，川下側の業務領域を含んだ展開，ならびに最適化手法に関し ては改善の余地がある。

以下では，まず，先行研究に基づいて，建築生産情報の確定過程 の特徵をまとめ, 次に本研究でいう建築生産情報確定工程の領域と
その確定工程に組み込むべきルールを明らかにする。その後，近傍 探索法を使った建築生産情報確定工程の最適化方法について述心゙， 最後に実プロジェクトに適用した結果の考察を行い,ここで提案し た最適化方法の有効性を確認する。

\section{3 本研究の特徴}

本研究の特徵を以下に示す。このうち, (1) (3)は先行研究 ${ }^{6) \sim 10)}$ を発展的に継承したものであり，(4)(5)は本研究で新たに提案する知 見である。

(1) 発注者から見た設計者と生産者の利害相反の明確化

設計者と生産者（生産者とは図 1 にいう施工者，部品製造者を包 含する意味で用いる）の利害は，次のように相反するものとした。 設計者の傾向…十分に設計内容の検討を行いたいため，建築生産情 報確定を遅らせる方向に働く。

生産者の傾向‥生産過程における不測の事態に備えたいこと, 施工 前のリードタイムを長くしてコスト低減を図ること等のため，建築 生産情報確定を早める方向に働く。

これに対し，発注者は設計者の主張を受容し，生産者の主張を排 除する傾向にある。発注者の希望を直接的に反映させるのは設計者 であるとして，設計者の主張は理解される一方，生産者の主張は発 注者から理解されにくい。しかし，建築生産情報の早期確定によっ
*1 大林組 工修

*2 京都大学大学院建築学専攻 助教授. 工博

*3 京都大学大学院建築学専攻 助手・博士 (理学)

*4 京都大学国際融合創造センタ一 助教授・博士 (工学)
Obayashi Corporation, M. Eng.

Assoc. Prof., Dept. of Architecture and Architectural Systems, Kyoto University, Dr. Eng.

Instructor, Dept. of Architecture and Architectural Systems, Kyoto University, Dr. Sci.

Assoc. Prof., International Innovation Center, Kyoto University, Dr. Eng. 


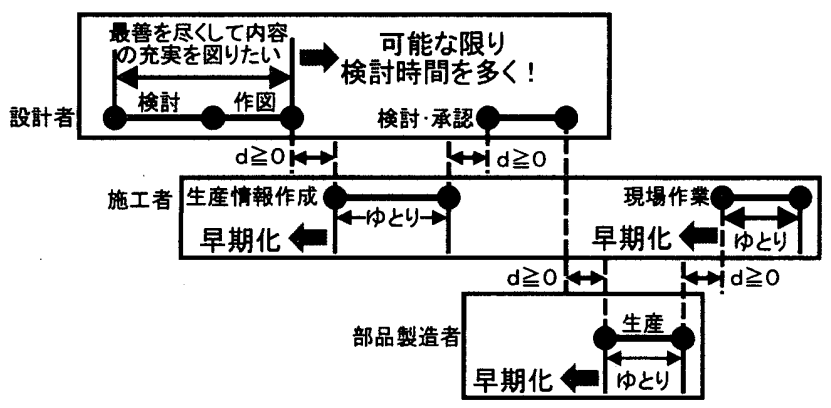

図 1 設計者と施工者・部品製造者のトレードオフ

て様々な利益が生じることがわかれば, 設計内容の検討に時間をか けるのがよいか，一定の範囲で早期化して利益を享受した方がよい か, 判断することができる。

本研究は，こうした状況で発注者の判断材料となる情報を提供す ることができるシステムを提案することを特徽としている。

（2）建筑生産情報確定における「先行・後続関係」および「同時並 行検討関倸」の明確化

設計内容は，設計段階ですべて確定され，生産者はそれに基づい て建築生産情報を作成し，生産にあたるのが原則である。しかし， 実際には，設計者ができる限り検討期間を確保する傾向があり，個 別の建築生産情報ごとに，生産活動に間に合うように設計内容が確 定されていく。まず生産工期にしたがって確定の最終期限が定まる が，その条件を満たす範囲で，以下に述べる，建築生産情報相互の

「先行・後続関係」「同時並行検討関係」に基づき, 建築生産情報が 順次確定される。

関連する情報を同時並行的に検討することにより，設計者にとっ ては設計全体の総合的な関連性を検討することが容易になり，生産 者の作業所長にとっては, 各部分の整合性を確認するのに好都合と なる。その結果, 建築生産情報は, 先行·後続関倸を考慮した上で, 関連情報ごとに同時並行の形で検討, 確定される。

本研究では, 建築生産情報の確定工程の仕組みを作成するために, それぞれの建築生産情報相互の前後関係, すなわち確定の「先行 · 後続関係」および, 建築生産情報が関連する情報ごとに群を形成し， その群ごとに確定していく「同時並行検討関係」の原則を採用する。

（3）建築生産情報の遅延防止策の明確化と早期確定による利益の 明確化

建築生産情報の確定遅延は, 後工程である工場や現場での生産工 程を乱す。それに対して, 経験豊かな作業所長は, 万全の予防策を 講じるとともに，戦略的に前倒し確定することにより，工事費の抑 制，工期の短縮や安定化に努めてきた。

本研究では，確定遅延防止のために採られてきた方策を明らかに するとともに，計画的に建筑生産情報確定を早期化し，工事費の抑 制，工期の短縮や安定化につなげてきた早期化による利益を事例に より算定し，その傾向を明らかにした。

（4）フロートを活用した確定の遅延防止および早期化

建築生産情報確定の遅延が生じるおそれがある場合, 経験的に, それぞれの工程に含まれるフロートによって調整してきた。確定を 早期化する場合にもフロートを縮めるなどの方法で対処してきた。

本研究では, 個々の作業に含まれるフロートの性格を, Explicit フロートと Implicit フロート（3.3 参照）に区別し，建築生産情報確 定工程の遅延防止と計画的早期化のために，建築生産情報相互の先
行・後続の関倸を保ちながら，工程を短縮した解を求めることので きる方法を提案している。また，本研究にて作成した建築生産情報 確定工程上で, 工期の延伸を伴わない範囲で Network フロート (3.4.1 参照）を定義し，工程早期化による作業集中の回避，投入労務の平 準化を考慮している。

（5）近傍探索法（4.1 参照）を用いた生産情報確定工程の最適化方 法の提案

建筑生産情報確定過程の明確化，および確定の遅延防止や早期化 による利害得失の明確化により, 当該プロジェクトに最適な建筑生 産情報確定工程を合理的に求めることが可能となる。

本研究では，フロートの活用，特定作業に関する KeyDate（3.5.3 参照）の操作によって，当該プロジェクトにとって最適の建築生産 情報確定工程を設定する方法として，近傍探索法を採用する。実プ ロジェクトに基づき工程の最適化を行い, 初期工程の結果と比較し, その有効性を確認する。

\section{2. 建築生産情報の確定過程}

先行研究 6) (10)に基づき，建築生産情報の確定過程の特徽をまとめ ると，以下のとおりである。

(1)建築生産情報の確定時期を定める要素

(1)生産工程上, 確定しなければならない期限

(2)設計者や発注者による意思決定に必要な工期

(2)建築生産情報の確定順序

(1)先行·後続関係によって規定されるもの

(2)同時並行検討関係によって規定されるもの

(3)建築生産情報の早期確定に期待されるメリット

(1)工事費抑制

(2)建筑生産情報確定工程そのものの作成費用抑制,

(3)工期安定化

(4)個別の建築生産情報確定の遅延回避策

(1)建築生産情報確定工程の作成と各主体の合意形成

(2)余裕工期の活用

\section{3. 建築生産情報確定工程の構築}

\section{1 建築生産情報確定工程の領域}

本研究では，建築生産情報確定工程の領域を，図 2 に示すとおり 「実施設計開始以後」から「施工図の検討・承認」までに拡張する。 以下にその理由を示す。

(1) 企画, 基本設計段階での設計者の主な行為は2つある。1つは 「発注者との打ち合わせ」「資料検討」であり，試行錯誤を経て発注 者の希望を具現化するための作業である。この作業は, 設計労務の 追加投入によって早期化を図ることが困難で，かつ，作業量の標準 化が難しく，「工数」の概念で捉えにくい。2つは，「立案一打ち合 わせー変更」の繰り返しによる設計内容の確定であり,プロジェク トによって大きな差異が存在し，「工程」という概念で捉えにくい。 (2) 実施設計段階における設計者の主な行為は, 「設計内容の詳細 化」「実施設計図書の作成」であり，基本設計での検討が十分ならば， 大きな変更を伴うことが少ない。したがって, 作業量を定量化して 捉えやすく，また，労務投入量の増加で早期化を図ることが可能で ある。 
（3）施工図作成段階における主な行為は2つある。1つは, 生産者 による「施工図，製作図作成」と「整合チェック」であり，2つは, 発注者と設計者による「施工図, 製作図の検討・承認」である。これ らは大幅な設計変更を伴わなければ，作業量を定量化しやすく，ま た，労務投入量の増加によって早期化を図ることが可能である。

以上の理由から, 本研究での「建築生産情報確定工程の作成」な らびに「建築生産情報確定工程の最適化」を行う上で考慮すべき作 業領域を,「赛施設計開始以後」から「施工図, 製作図の検討, 承認」 までとし，上述の確定工程作成とその最適化を行う。

\section{2 各段陼における作業内容}

本研究における, 建築生産情報の流れのモデルと, 設計者, 主施 工者 (一般的にはゼネコン), 専門技術別生産者 (一般的にはサブコ ン), 部品・部材製造者（一般的にはメーカー）の各主体の関わり方 を図 2 に示寸。図 2 における用語は以下の意昧である。

(1)実施設計段階（「検討」一「作図」）

「検討」…検討一作図·修正」の繰り返しでの検討作業の総称

「作図」…「検討一作図・修正」の繰り返しでの作図作業の総称 (2)施工図作成段階（「作図」一「検討·承認」）

「作図」…主施工者や専門技術別生産者, 部品・部材製造者による 施工図・製作図作成から主施工者の整合チェックまでを含む

「検討・承認」…検討開始以後の設計者による詳細な検討を含む

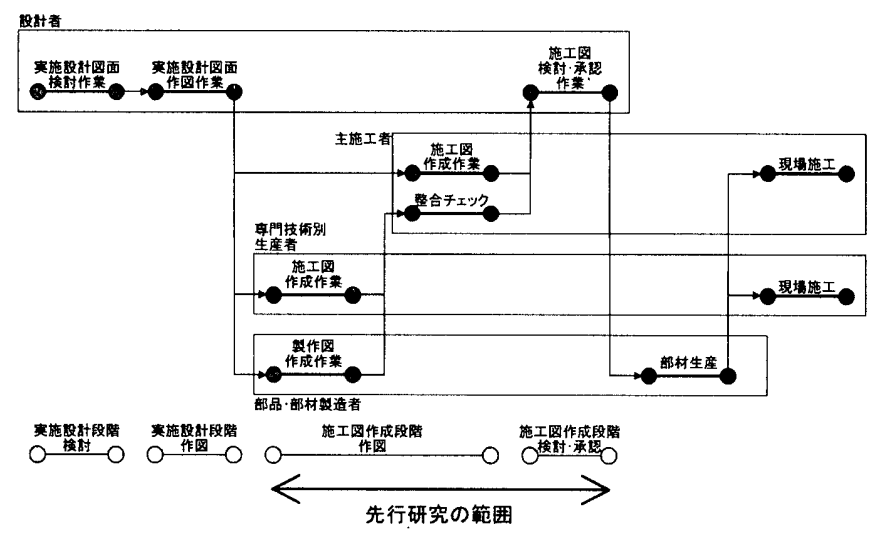

図 2 建築生産情報の流れのモデル

\section{3 個別の建築生産情報確定工程のルール}

建築生産情報確定工程に見込まれる余裕工期を，作業工程に含ま れるフロートとして, 費用増加を伴わないで短縮可能な Explicit フ ロートと, 短縮にあたって, 作業人工の追加投入などのために費用 の增加を伴う Implicit フロートに分けて考える。

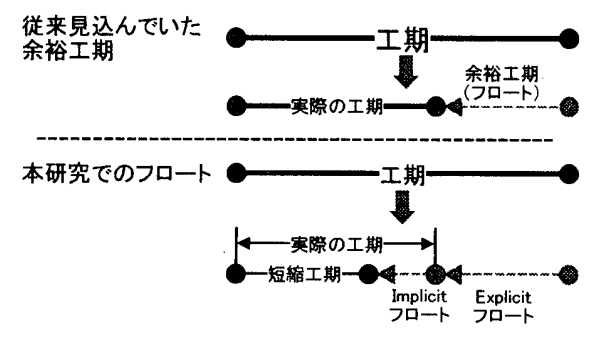

図 3 フロートの概念図

3.4 複数の建築生産情報の相互関係に基づく確定工程のルール

建築生産情報の確定順序について,いくつかのルールを設定する。 ここで扱う建築生産情報は表 1 のとおりである。
表 1 本研究で対象とする建築生産情報

\begin{tabular}{|c|c|c|c|c|c|}
\hline \multirow{4}{*}{$\begin{array}{l}\text { 实施設計 } \\
\text { 段階 }\end{array}$} & $\begin{array}{c}\text { 意匠系 } \\
\text { 設計圆要 }\end{array}$ & \begin{tabular}{|l} 
平面图 \\
断面图 \\
展開图 \\
\end{tabular} & $\begin{array}{l}\text { 立面图 } \\
\text { 吉上表 } \\
\text { 部分群細図 }\end{array}$ & $\begin{array}{l}\text { 置图 } \\
\text { 知計图 } \\
\text { 天茾伏囱 }\end{array}$ & $\begin{array}{l}\text { 居根伏图 } \\
\text { 平面詳細図 } \\
\text { 建县リスト } \\
\end{array}$ \\
\hline & 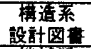 & 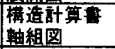 & $\begin{array}{l}\text { 伏离 } \\
\text { 部分羘細图 }\end{array}$ & 柱·祭・スラプリ & $\pi \vdash$ \\
\hline & 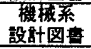 & 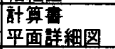 & 系統圂 & 霹哭リスト & 平面図 \\
\hline & 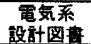 & 殒十算竟 & 系統図 & 機器リスト & 平面图 \\
\hline \multicolumn{2}{|c|}{ 施工图作成段階 } & 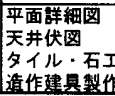 & 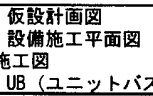 & 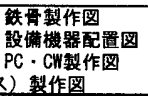 & 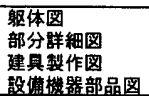 \\
\hline
\end{tabular}

\subsection{1 建築生産情報の相互関係に基づく確定工程のルール}

(1)実施設計段階

a. 先行·後続関係の場合の制約条件

後続図面の作図は，先行図面の作図完了後に着手寸る。すなおち 図 4 の $\mathrm{d}$ は $\mathrm{d} \geqq 0$ を満足する。

b ，同時並行検討の場合の制約条件

同時並行検討関係にある場合は，検討期間が重なる必要がある。 すなわち図 4 の斜線部が存在する。

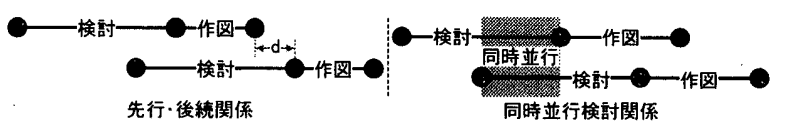

図 4 実施設計段階の相互関係のルール

(2)施工図作成段階

a . 先行·後続関係の場合の制約条件

後続図面の検討·承認は，先行図面の検討・承認後に着手する。す なわち図 5 の $\mathrm{d}$ は $\mathrm{d} \geqq 0$ を満足する。

b ．同時並行検討関係の場合の制約条件

同時並行検討関係にある場合は，検討期間が重なる必要がある。 すなわち図 5 の斜線部が存在する。

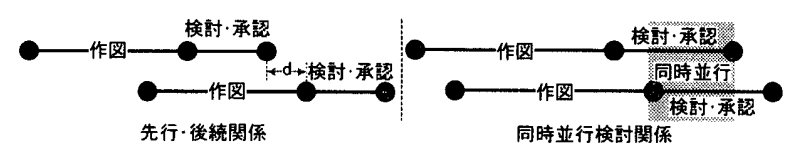

図 5 施工図作成段階の相互関係のルール

(3)Network フロート

工程ネットワーク上で，クリティカルパス $(\mathrm{CP})$ 上にない作業に含 まれるトータルフロート(TF)の範囲内で, 作業開始遅れ時間を Network フロートとして与え，作業開始時間を変化させる。

\subsection{2 建築生産情報の相互関係の特定}

建築生産情報の相互関係を，経験豊富な奏務者へのヒアリングを もとに各図面について取りまとめたものを図 6 に示す。

\section{5 確定早期化のルール}

建築生産情報を早期に確定することは, 工程の遅延防止に加えて, 工事費の抑制，工期短縮などの戦略的目的のために行われる。その 程度は, 早期確定により期待される利益と制約条件のバランスで決 まる。ここではそのモデル化のためのの条件を以下にまとめる。

3.5 .1 各作業の工数と使用可能なフロート

建築生産情報早期確定のための, 設計者や生産者による図面作成, 主施工者による整合チェック,および設計者による検討・承認作業の 早期集中への対応を制約条件とするために，各作業の作業量と，前 出の Explicitフロート, Implicitフロートを設定する。 


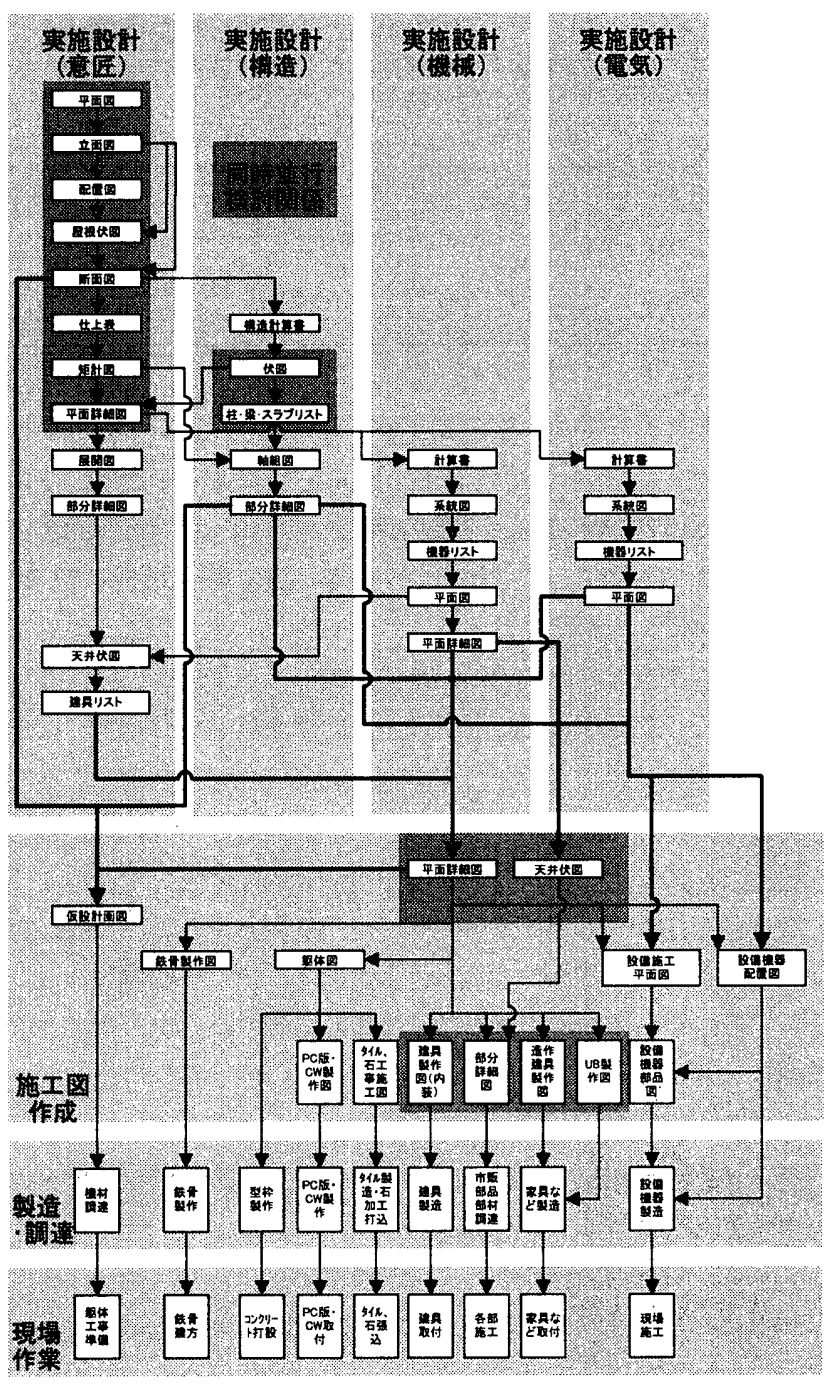

図 6 建築生産情報の相互関係

\subsection{2 作業集中回避の制約条件}

(1)個別作業の工期短縮による作業集中に関しては工程中のフロート で対応する。

(2)複数作業が同時期に重複する場合の作業集中に関しては作業担当 者の工程能力が重複の程度を制約することとする。

\subsubsection{KeyDate の設定による工程の早期化}

全体工程の早期化を指向することに加えて, 特定の作業に守るべ き確定期日を KeyDate（キーデート）として設定し, 部分工程の早 期化を行う。

\section{5 .4 早期確定による費用の抑制}

実務担当者に行ったヒアリング（1999 年 11 月実施）をもとに， 早期確定によって費用抑制が可能な生産工程の特定と, 費用抑制が 可能となるリードタイム (準備期間)，費用抑制の全体工事に対する 割合を表 2 のおおり設定する。

\section{4. 建築生産情報確定工程の最適化方法}

本研究における最適化のフローを図 7 に示す。

\section{1 近傍探索法の概要}

本研究では, 最適化手法として, 近傍探索法を用いる。近傍探索 法は, 組合せ最適化問題などで頻繁に用いられる近似解法であって， 探索範囲を近傍という概念を用いて効率よく局所的に限定する。解

\section{表 2 費用抑制が可能な生産工程に関する情報}

\begin{tabular}{|c|c|c|c|}
\hline 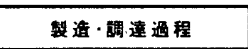 & $\begin{array}{c}\text { 早期発注表 } \\
\text { も的 }\end{array}$ & リードタイム & 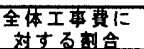 \\
\hline 鉄唪作 & 铁合製作圆 & $\overline{30 日}$ & $0.28 \%$ \\
\hline 型挌繁作 & 盤体图 & 30 日 & $0.15 \%$ \\
\hline PC版 $\cdot$ CW製作 & PC・CW慜作图 & 30 日 & $0.40 \%$ \\
\hline タイル製造・石加工打込 & タイル・石工事施工图 & 30 日 & $0.20 \%$ \\
\hline 建具慜造 & 建具嘍作图 & 60日 & $0.60 \%$ \\
\hline UB（ユニットバス）製作 & UB慗作圂 & 60 日 & $0.15 \%$ \\
\hline 家具等製逶 & 逶作建具製作图 & 30日 & $0.80 \%$ \\
\hline 設槅機器製造 & 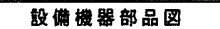 & 40日 & $0.48 \%$ \\
\hline
\end{tabular}

の近傍の中から，現在までの最良解などと比較して，より優れた解 があれば,そちらを選択することを繰り返して行う反復解法である。 近傍探索法ではタブー探索法や遺伝的アルゴリズム ${ }^{22}$ が用いられる ことも多いが，これらの手法では近傍構造が複雑になり，パラメー 夕設定等に時間を費やされる傾向がある。そのため最近では複雑で 大規模な問題においては，近傍探索法のうち単純で性能の良い局所 探索法（local search） ${ }^{13)}$ が用いられている。

\section{2 建築生産情報確定工程のデータ構造}

最適化に際し，前章で構策した建築生産情報確定工程はアローダ イアグラムで表現される。各作業（アクティビティ）および作業間 の関係を示すダミーアクティビティは作業 $(\mathrm{i}, \mathrm{j})$ )形で表す。各作業の データは，各項目の添字が開始ノード，終了ノードを意味する。各 作業 $(\mathrm{i}, \mathrm{j})$ には，以下の 8 項目の情報が含まれる。なお図 7 にいう作業 系列は表 3 に示すとおりで, 意匠, 構造, 生産等の各作業担当者の 作業群を表している。

$\mathrm{M}_{\mathrm{I}, \mathrm{j}}\left[\right.$ man $\cdot$ day] : 工数, $\mathrm{N}_{\mathrm{i}, \mathrm{j}}[\mathrm{man}]$ : 作業担当人数

$\mathrm{EF}_{\mathrm{i}, \mathrm{j}}[\mathrm{man} \cdot \mathrm{day}]$ : 使用可能 Explicit フロート数

$\mathrm{IF}_{\mathrm{i}, \mathrm{j}}$ [man・day] : 使用可能 Implicit フロート数

$\mathrm{FF}_{\mathrm{i}, \mathrm{j}}[\mathrm{man} \cdot \mathrm{day}]$ : 初期使用可能アロート数

$\mathrm{SG}_{\mathrm{i}, \mathrm{j}}$ [number] : 同時並行検討グループ番号

$\mathrm{LT}_{\mathrm{i}, \mathrm{j}}[\mathrm{day}]$ : リードタイム, $\mathrm{EC}_{\mathrm{i}, \mathrm{j}}[\%]$ : 早期化コスト
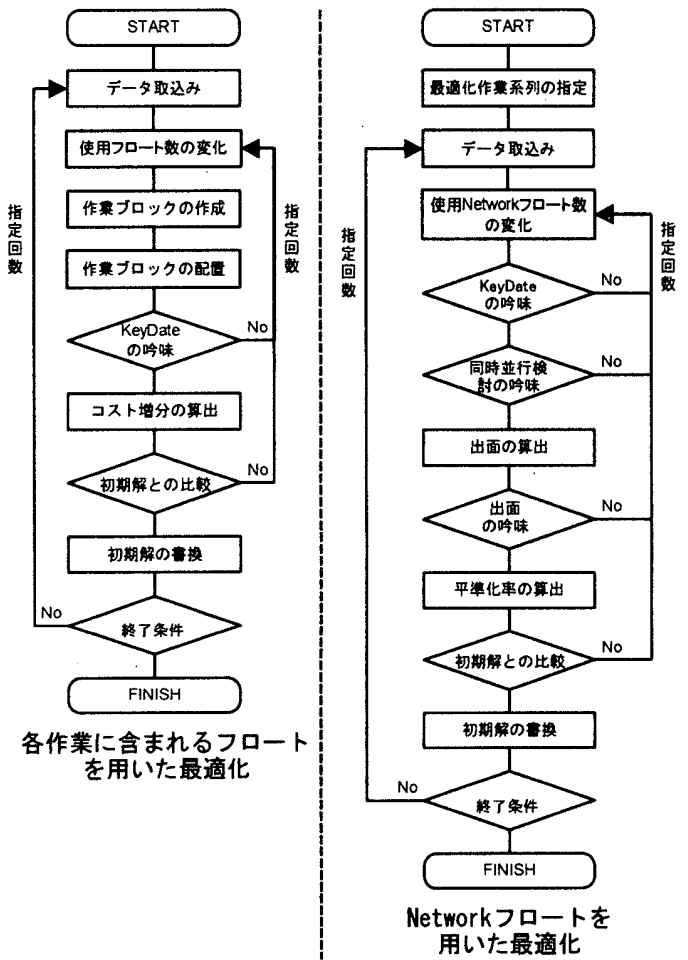

図 7 建築生産情報確定工程の最適化フロー 


\section{表 3 作業系列番号と作業担当者の対応}

\begin{tabular}{|c|c|}
\hline 作蕃系列番号 & 作羓担当者 \\
\hline 1 & 設訐者の意丘系担当者 \\
\hline 2 & 設計者の構造系担当者 \\
\hline 3 & 設計者の機珹設備系担当者 \\
\hline 4 & 設計者の電気設備系担当者 \\
\hline 5 & 生産担当者 \\
\hline 6 & 設計者の設計監理担当者 \\
\hline
\end{tabular}

\section{3 各作業に含まれるフロートを用いた最適化}

各作業に含まれるフロートを用いた最適化では，近傍探索として 各作業のフロート使用数を変化させて工程ネットワークを構築し，

KeyDate の制約条件を守っているかを判定した上で, Implicit フロー 卜使用によるコスト增分 $(\mathrm{C})$ を算出する。これと現在までの最良解と の比較検討を行う。そして，そのCの最小化を図る。

$$
\mathrm{C} \rightarrow \text { 最小化 } \cdots(4-1)
$$

(1)データの取込み

(2)使用フロート数の変化

使用フロート数を変化させる作業をランダムに選択し，使用可能 Explicit フロート数と使用可能 Implicit フロート数の合計の範囲内で, 使用フロート数を発生させる。

(3)作業ブロックの作成

各作業のデータから，フロートを用いての早期化を行い，縦軸を 作業担当人数，横軸を作業日数とする，作業ブロックを作成する。 その作業は，以下の手順で行われる。

(1) 作業日数の算出と標準作業ブロックの作成

工数 $\mathrm{M}_{\mathrm{i}, \mathrm{j}}$ と作業担当人数 $\mathrm{N}_{\mathrm{i}, \mathrm{j}}$ から , 式(4-2)により作業日数 $\mathrm{D}_{\mathrm{i}, \mathrm{j}}$ を算 出する。

$$
\begin{aligned}
& D_{i, j}=M_{i, j} / N_{i, j} \quad \text { (切上げ) } \\
& D_{i, j}[\text { day }]: \text { 作業日数 }
\end{aligned}
$$

縦軸を作業担当人数 $\mathrm{N}_{\mathrm{i}, \mathrm{j}}$, 横軸を作業日数 $\mathrm{D}_{\mathrm{i}, \mathrm{j}}$ として，作業ブロッ クを作成する。この作業ブロックを，標準作業ブロックと定義する。

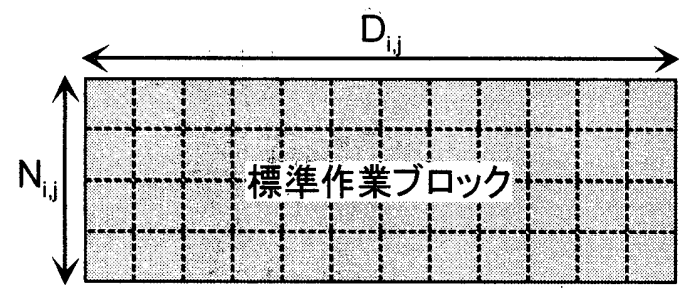

図 8 標準作業ブロック

（2）初期使用可能フロート数による作業日数の短縮

初期使用可能フロート数 $\mathrm{FF}_{\mathrm{i}, \mathrm{j}}$ から，式(4-3)を用いてフロート使用 によって短縮されるフロート短縮日数 $\mathrm{FD}_{\mathrm{i}, \mathrm{j}}$ を求め, 短縮された日数 分を標準作業ブロックから取り去る。

$$
\begin{aligned}
& F D_{i, j}=F F_{i, j} / N_{i, j} \quad \text { (切捨て) } \\
& R D_{i, j}=D_{i, j}-F D_{i, j} \\
& R F_{i, j}=N_{i, j} \times F D_{i, j} \\
& F D_{i, j}[\text { day }]: \text { フロート短縮日数 } \\
& R D_{i, j} \text { [day]: 実作業日数 } \\
& R F_{i, j} \text { [manday]: 実使用フロート数 }
\end{aligned}
$$

初期使用可能フロート数 $\mathrm{FF}_{\mathrm{i}, \mathrm{j}}$ から, 短縮可能な日数をフロート短 縮日数 $\mathrm{FD}_{\mathrm{i}, \mathrm{j}}$, 短縮された作用日数を実作業日数 $\mathrm{RD}_{\mathrm{i}, \mathrm{j}}$, 実際に作業日 数短縮に用いられるフロート数を実使用フロート数 $\mathrm{RF}_{\mathrm{i}, \mathrm{j}}$ とする。

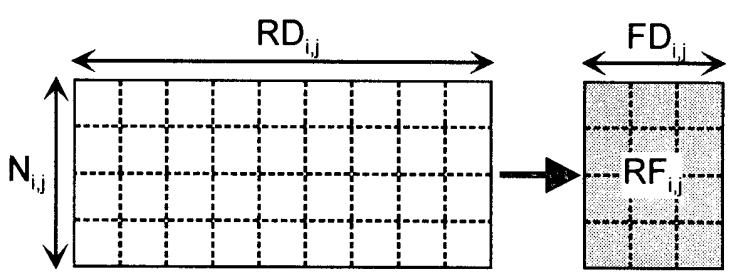

図 9 実使用フロート数による作業日数の短縮

(3) フロートの性質の特定と作業ブロックの完成

前項の実使用フロート数から，式(4-4)を用いて Explicit フロート として処理できるものと Implicit フロートとして労務の上積みを伴 うものに区分する。

$$
\begin{aligned}
& \left\{\begin{array}{l}
E F^{\prime}{ }_{i, j}=R F_{i, j} \\
I F^{\prime}{ }_{i, j}=0
\end{array} \quad\left(R F_{i, j} \leqq E F_{i, j}\right)\right. \\
& \left\{\begin{array}{l}
E F^{\prime}{ }_{i, j}=E F_{i, j} \\
I F^{\prime}{ }_{i, j}=R F_{i, j}-E F^{\prime}{ }_{i, j}
\end{array} \quad\left(R F_{i, j}>E F_{i, j}\right) \cdots(4-4)\right.
\end{aligned}
$$

$E F^{\prime}{ }_{i, j}$ [man · day]: 実使用 Explicitフロート数

$I F_{i, j}^{\prime}$ [man · day]: 実使用Implicitフロート数

本研究においては，実使用フロート数 $\mathrm{RF}_{\mathrm{i}, \mathrm{j}}$ が使用可能 Explicit フ ロート数 $\mathrm{EF}_{\mathrm{i}, \mathrm{j}}$ を超えた場合, 超過分は Implicit フロートとして, 労 務の上積みを行うものとする。

次に，式(4-5)を用いて実使用 Implicit フロート数の上積みを行う。

$$
\begin{aligned}
& R D 2_{i, j}=I F_{i, j}^{\prime} / 1 \\
& R D 1_{i, j}=R D_{i, j}-R D 2_{i, j} \\
& R N_{i, j}=N_{i, j}+1 \\
& R D 1_{i, j} \text { [day]: 初期作業日数 } \\
& R D 2_{i, j} \text { day]: 最終追加投入日数 } \\
& R N_{i, j} \text { [man]: 最終担当人数 }
\end{aligned}
$$

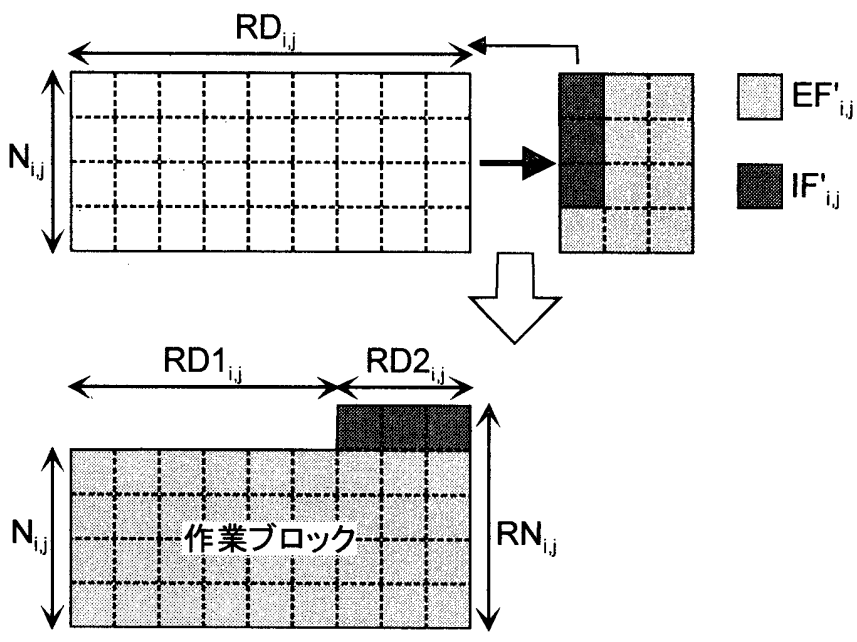

図10 作業ブロック 
Implicit フロートの使用分は, 作業の終盤部分で 1 日あたり 1 人工 の労務を追加投入するとして考え，これにより，初期作業日数 $R D 1_{i j}$ と最終追加投入日数 $R D 2_{i, j}$, 作業担当人数 $N_{i, j}$ と最終担当人数 $R N_{i, j}$ からなる作業ブロックが作成される。

(4)作業ブロックの配置

PERT(Program Evaluation and Review Technique)手法を用いて最早 開始日を算出し，各作業 $(\mathrm{i}, \mathrm{j})$ の最早開始日を作業開始日 $\mathrm{ST}_{\mathrm{i}, \mathrm{j}}$ とする 工程ネットワークを作成する。

(5)KeyDate の吟味

KeyDate を指定した作業に関して，作業終了日が $\mathrm{KD}_{\mathrm{i}, \mathrm{j}}$ を守ってい るか，式(4-6)で確認する。

$$
\mathrm{ST}_{\mathrm{i}, \mathrm{j}}+\mathrm{RD}_{\mathrm{i}, \mathrm{j}} \leqq \mathrm{KD}_{\mathrm{i}, \mathrm{j}} \quad \cdots(4-6)
$$

(6)Implicit フロート使用によるコスト増分の算出

式(4-7)で工事費の增分(C)を算出する。

$$
\mathrm{C}=\Sigma \mathrm{IF}^{\prime} \times \mathrm{RI}
$$

$C[\%]$ : 工事費増加割合

$\mathrm{RI}[\% /(\operatorname{man} \cdot$ day $)]$ : Implicit フロート 1 人工使用による工 事費増加割合

(7)最良解との比較

式(4-8)を用いて， C と最良解のコスト増分 $\mathrm{C}_{\mathrm{i}}$ を比較する。

$$
\mathrm{C}<\mathrm{C}_{\mathrm{i}} \quad \cdots(4-8)
$$

\section{8)最良解の書換}

(9)終了条件の判断

以上のフローによって，各作業に含まれるフロートを利用した最 適化を行う。次いで, Network フロートを用いた最適化を行う。

4.4 Network フロートを用いた建築生産情報確定工程の最適化

Network フロート数を変化させ，各制約条件を守っているかを判 断した上で平準化率を算出，最良解との比較検討を行う。

(1)最適化作業系列の指定

(2)データ取込み

(3)使用 Network フロート数の変化

a. Network フロートの発生

指定された作業系列に属するダミーアクティビティの中から， Network フロートを変化させる作業を抽出する。そして, トータル フロートの範囲内で Network フロートを発生させる。

b ．作業ブロックの再配置

Network フロートを発生させることによって，その後続作業の開 始日が遅れることから, PERT 手法を用いて最早開始日とトータル フロートの再計算を行い, その結果求められる各作業の最早開始日 を実作業開始日 $\mathrm{RST}_{\mathrm{i}, \mathrm{j}}$ とする。

(4)KeyDate $の$ 吟味

(5)同時並行検討関係の吟味

各作業の同時並行検討グループ番号 $\mathrm{WG}_{\mathrm{i}, \mathrm{j}}$ が等しいものに関して, 同時並行検討グループ内の任意の $2 つ の$ 作業に関して，式(4-9)によ る判別を，すべての組み合わせに関して行う。

$$
\begin{aligned}
& 2 つ \text { 作業(I,j),(k,I)に関して } \\
& \operatorname{RST}_{\mathrm{i}, \mathrm{j}} \leqq \mathrm{RST}_{\mathrm{k} . \mathrm{l}}<\mathrm{RST}_{\mathrm{i}, \mathrm{j}}+\mathrm{RD}_{\mathrm{i}, \mathrm{j}} \\
& \text { または }
\end{aligned}
$$

(6)出面の算出

(7)出面の吟味

各作業系列の出面上限 $U_{\mathrm{g}}$ を守っているか，式(4-10)で吟味する。 全作業期間に関して

$\mathrm{u}(\mathrm{g}, \mathrm{t}) \leqq \mathrm{U}_{\mathrm{g}}$

$\mathrm{u}(\mathrm{g}, \mathrm{t})$ : 作業系列番号 $\mathrm{g}$ の時間 $\mathrm{t}$ における人数を示寸関数

(8)平淮化率の算出

指定された作業系列に関して，式(4-11)〜(4-14)を用いて，平準化 率 $\mathrm{LR}_{\mathrm{g}}$ を算出する。

$$
\begin{aligned}
\mathrm{LR}_{\mathrm{g}} & =\phi_{\mathrm{g}}\left(\left(\psi_{\mathrm{g}} \times \mathrm{T}_{\mathrm{g}}\right) \times 100\right. \\
\phi_{\mathrm{g}} & =\Sigma \mathrm{u}(\mathrm{g}, \mathrm{t}) \\
\psi_{\mathrm{g}} & =\max (\mathrm{u}(\mathrm{g}, \mathrm{t})) \\
\mathrm{T}_{\mathrm{g}} & =\mathrm{T}_{2}-\mathrm{T}_{1}
\end{aligned}
$$

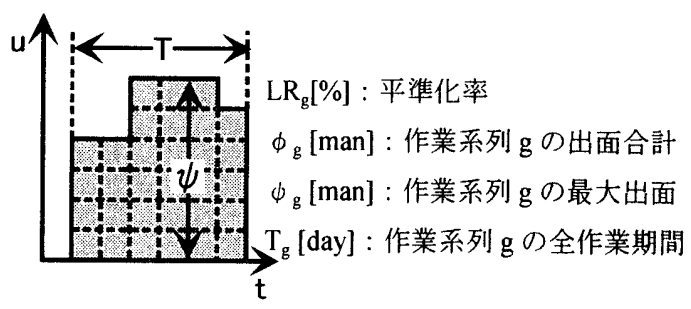

図 11 平準化率

(9)最良解との比較

指定された作業系列において, 式(4-15)を用いて, 平淮化率 $\mathrm{LR}_{\mathrm{g}}$ と最良解の平準化率 $\mathrm{LRI}_{\mathrm{g}}$ を比較する。

(10)最良解の書換

$$
\mathrm{LR}_{\mathrm{g}}>\mathrm{LRI}_{\mathrm{g}}
$$

(11)終了条件の判断

\begin{tabular}{|c|c|c|c|}
\hline \multirow{2}{*}{ 角途 } & \multicolumn{3}{|c|}{ 中高層集夻住宅 } \\
\hline & 延床面積 & 17. & \\
\hline \multirow{4}{*}{ 規模 - 構造 } & A棟 & 地上 11 階 & SRG道 \\
\hline & B棟 & 地上 13 苤 & SRC道 \\
\hline & C棟 & 地上 14 階 & SRC追 \\
\hline & D棟 & 地上10階 & RC造 \\
\hline
\end{tabular}

本研究においては，建築生産情報確定工程の構築後，まず 4.3 の 「各作業に含まれるフロートを用いた最適化」を行う。そして, 4.3 の最適解で求められた最適解に関して, Network フロートを変化さ せ，作業集中の回避，投入労務の平淮化を行う。

\section{5. 実プロジェクトへの適用と検証}

本章では，これまで述べてきた建築生産情報確定工程の最適化方 法を，実プロジェクトに適用し，最適化の結果を検証する。

5.1 対象プロジェクト

適用対象プロジェクトの概要を表 4 に示す。

表 4 対象プロジェクトの概要

\section{2 最適化を適用する工程の作成}

\section{2 .1 初期工程}

初期工程は 3 種類のフロート (Explicit, Implicit, Network) を全 く使わず，各作業の最早開始日を実作業開始日とする工程（全作業 完了日 334 日) である。図 12 にその結果を示す。表 5 はその時の 各作業系列の最大出面および平淮化率である。 


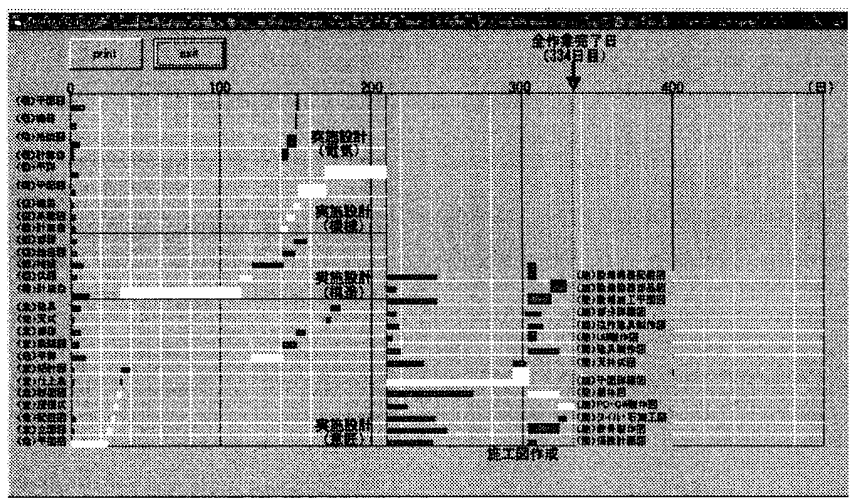

図 12 初期工程表

表 5 初期工程での最大出面と平準化率

\begin{tabular}{c|c|c}
\hline 作業系列番号 & 最大出面 (人) & 平準化率 (\%) \\
\hline \hline 1 & 12 & 5.72 \\
2 & 5 & 30.06 \\
3 & 5 & 13.62 \\
4 & 5 & 6.18 \\
5 & 14 & 32.31 \\
6 & 14 & 41.61 \\
\hline
\end{tabular}

\section{2 .2 改良初期工程}

初期工程に関して, 出面上限 $U_{\mathrm{g}}$ を設定せずに, Network フロート を用いて労務の平準化に関する最適化を行った。これを改良初期工 程と呼び，その結果を図 13 および表 6 に示す。

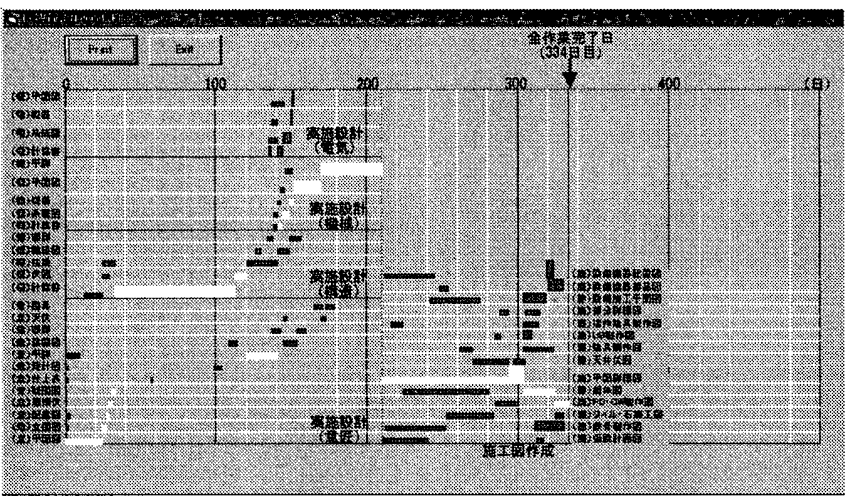

図13 改良初期工程表

表 6 改良初期工程での最大出面と平準化率

\begin{tabular}{c|c|c}
\hline 作業系列番号 & 最大出面 $($ 人) & 平準化率 $(\%)$ \\
\hline \hline 1 & 8 & 8.59 \\
2 & 2 & 81.38 \\
3 & 2 & 92.86 \\
4 & 3 & 92.16 \\
5 & 5 & 80.85 \\
6 & 9 & 64.72 \\
\hline
\end{tabular}

表 5 に比べ表 6 では相当程度, 労務の平準化が図られていること がわかる。表 6 で平準化率の低い作業系列 1，6 について以下に考察 する。作業系列 1 は，8 種類の作業が同時並行検討関係にあるため, 最大出面の下限が 8 人となっているが, $\mathrm{CP}$ 上の作業が多いため作業 開始時間の自由度が少なく, 平準化が困難である。作業系列 6 は,
工程の終盤部分のため，作業開始時間の自由度が少なく，平準化が 低い状態にとどまっている。

\subsection{KeyDate を指定した最適化}

ここでは表 4 に示すプロジェクトにおいて，3 種類のフロート全 てを使い，特定の作業の完了日を拘束した場合の最適化を試みた。 特定の作業をタイル・石工事施工図の検討・承認完了日とする。

タイル・石工事施工図の検討・承認完了の KeyDate を, 表 2 に示寸 工事費抑制効果が発生する 30 日のリードタイムを確保した場合の 最適化を行った。なお，工事費における設計費，施工図作成費の割 合と工数をもとに, Implicit フロート 1 人工当たりのコスト増分の比 率（RI）を工事費の $0.003 \%$ ／人工とする。

(1) 各作業に含まれるフロートを用いた最適化の結果

最適化の結果, 図 14 に示すように全作業完了日が 309 日となり, 図 12 の初期工程（全作業完了日 334 日）と比べて 25 日の早期化が 達成されている。

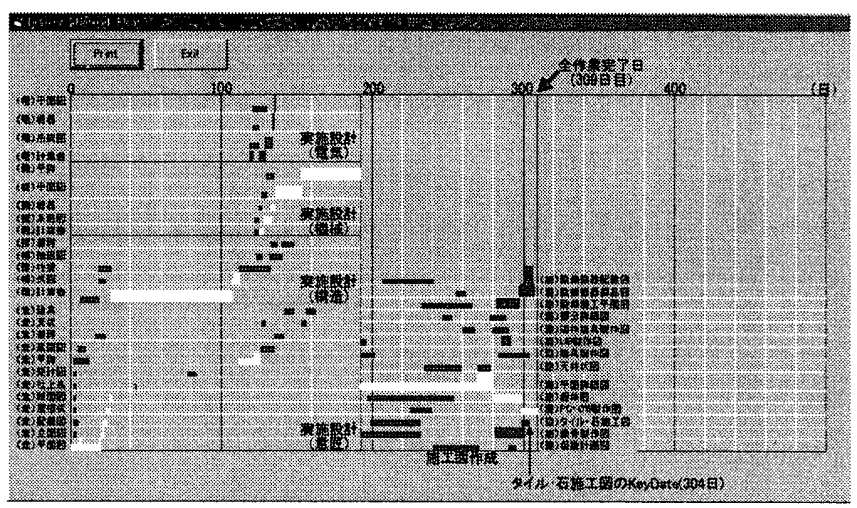

図14 KeyDate を設定した場合の最適化結果

表 7 使用フロート数

\begin{tabular}{|c|c|c|c|c|c|c|c|}
\hline 段階 & 作策系列 & 工程 & 作業 & 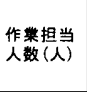 & $\begin{array}{c}\text { 使用可能 } \\
\text { Explicit } \\
\text { ᄀ五数 } \\
\text { (〈I) }\end{array}$ & 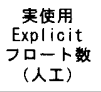 & 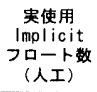 \\
\hline \multirow{8}{*}{$\begin{array}{l}\text { 実施 } \\
\text { 設計 }\end{array}$} & \multirow{5}{*}{ 意医系 } & 平面图 & 模討 & 1 & 0 & 0 & 1 \\
\hline & & 平面图 & 作图 & 1 & 2 & 2 & 1 \\
\hline & & 立面图 & 作图 & 1 & 0 & 0 & 1 \\
\hline & & 断面图 & 作图 & 1 & 1 & 1 & 0 \\
\hline & & 平面䛨細图 & 作图 & 1 & 4 & 4 & 3 \\
\hline & 舫造系 & 伏图 & 作图 & 1 & 0 & 0 & 3 \\
\hline & \multirow{2}{*}{ 權嗽系 } & 平面图 & 作图 & 1 & 2 & 2 & 0 \\
\hline & & 平面詳細图 & 作图 & 2 & 2 & 2 & 0 \\
\hline \multirow{2}{*}{$\begin{array}{c}\text { 施工図 } \\
\text { 作成 }\end{array}$} & 生産 & 平面辞組图 & 作图 & 1 & 5 & 5 & 1 \\
\hline & $\begin{array}{l}\text { 設計監理 } \\
\end{array}$ & 般体図 & 榙討·承認 & 1 & 1 & 1 & 0 \\
\hline & & & & & 合敦 & 17 & 10 \\
\hline
\end{tabular}

以下に算出された結果から読みとることができる特徴を述べる。 (1)フロートの使用（表 7 ）は全てクリティカルパス上の作業である。 (2)CP 上の全作業に関して，全ての Explicitフロートを使用した上で Implicitフロートを使用している。

(3)作業担当人数が 1 人の作業から Implicit フロートを順次使用して いる。すなわち Implicit フロートの使用は効率的であった。

(2) Network フロートを用いた最適化の結果

Network フロートを用いて, 労務の平淮化を行った。その結果を 表 8 に示す。ここで出面上限は表 6 に示された改良初期工程の結果 に 1 人を加えたものとした。表 6 と比べ，平準化率はさほど向上し ていない。これは KeyDate の制約が厳しいためである。 


\section{表 8 最大出面と平準化率}

\begin{tabular}{c|c|c|c}
\hline 作菜系列番号 & 出面上限 $($ 人) & 最大出面 $($ 人) & 平準化率 $(\%)$ \\
\hline \hline 1 & 9 & 8 & 8.95 \\
2 & 3 & 2 & 83.10 \\
3 & 3 & 2 & 99.29 \\
4 & 4 & 3 & 92.16 \\
5 & 6 & 6 & 80.18 \\
6 & 10 & 10 & 59.49 \\
\hline
\end{tabular}

（3）早期確定による工事費抑制効果

Implicit フロート使用による工事費増分は $10 \times 0.003 \%=0.03 \%$ あ り，最適化適用による工事費抑制は $0.20 \%$ である。つまり全体で $0.17 \%$ の事費抑制効果が生じたことになる。

\subsection{KeyDate を設定しない最適化}

前節では特定の作業の完了日を拘束したが, その拘束がない場合, さらに工期短縮，工事費抑制が図られると目される。そこで，それ らの拘束が全くない場合の最適化を試みた。前節と同様，工事費抑 制効果は表 2 に示すデータを使用した。

（1）各作業に含まれるフロートを用いた最適化の結果

最適化の結果, 全作業完了日が 280 日となり，図 12 の初期工程 （全作業完了日 334 日）と比べ，54日の早期化が達成された。算出 された結果から読みとることができる特徴は以下のとおりである。 (1)CP 上の全作業に関して，全てのフロートを使用している。

(2)工事費抑制効果のある作業完了日に影響を与える作業では, 全て のフロートを使用している。

（2） Network フロートを用いた最適化の結果

Network フロートを用いて平準化を行った結果を表 9 に示す。

\section{表 9 最大出面と平準化率}

\begin{tabular}{c|c|c|c}
\hline 作業系列番号 & 出面上限 $($ 人) & 最大出面 $($ 人) & 平準化率 $(\%)$ \\
\hline \hline 1 & 9 & 8 & 10.14 \\
2 & 3 & 3 & 64.48 \\
3 & 3 & 3 & 68.14 \\
4 & 4 & 3 & 92.16 \\
5 & 6 & 6 & 74.41 \\
6 & 10 & 10 & 63.33 \\
\hline
\end{tabular}

改良初期工程（表 6) に比べて, 平淮化率は改善されていない。 これは表 9 で最大出面が出面上限に達していることからわかるよう に，工事費抑制効果を得るために作業が集中した結果である。

(3) 早期確定による工事費抑制効果

Implicit フロート使用による工事費増分は $50 \times 0.003 \%=0.15 \%$ であ り，最適化適用による工事費抑制は $1.78 \%$ ある。つまり全体で $1.63 \%$ 厂事費抑制効果が生じたことになる。

\section{5 検証結果のまとめ}

検証結果を以下に列記する。

(1)本システムを活用することによって, 建築生産情報を早期に確定 することによる工期短縮，工事費抑制効果が定量的に把握できる。 (2)設計者と生産者の合意によって，KeyDate を設定した場合，それ らを設定しない場合に比べ，得られる効果は小さくなる。 (3)生産情報の早期確定を達成するためには，一方で労務の平淮化は 犠牲になる可能性がある。

\section{6. 結論}

本研究では，建築生産情報の確定過程を明らかにし，これを最適 化することを目的として，以下のことを行った。

(1)実務者への調查結果をもとに建策生産情報確定工程を構筑した。 (2)各作業に含まれるフロートおよび相互関係に基づくフロートを 用いた建築生産情報確定工程の最適化方法を提案した。

(3)建築生産情報確定工程について，発注者の判断材料となる情報を 提供することができるシステムを提案した。

(4)システムを実プロジェクトに適用して，その有効性を示した。

今後の課題には，(1)建築生産情報の早期確定による工事費抑制効 果のさらに詳細なデータの収集，(2)建築生産情報の早期確定によっ て得られる効果と労務平準化とのトレードオフを解消する方法の検 討，などがある。

\section{参考文献}

1) 加藤，北，他：統合建築システム「LORAN-T」の開発・実用化，日本建築 学会第 13 回情報・システム・利用・技術シンポジウム論文集，1990.12

2）石井，森本，上村：建築生産情報総合システム(SISC-T)の開発と展開，日本 建筑学会第 19 回情報・システム・利用・技術シンポジウム論文集，1996.12

3）八坂，塚越，坂野，若杉，谷村：構造設計情報の生産計画業務への多角的 活用の試み一躯体生産情報システムの開発一，日本建築学会第 12 回建築生産 と管理技術シンポジウム論文集, 1997.7

4）木本，古阪，遠藤，蘇，岩下：建築の生産設計に関寸る基碒的研究，日本 建築学会第 8 回建築生産と管理技術シンポジウム論文集, 1992.7

5) 金多, 古阪, 長岡, 木本，岡本：建築生産ブロセスの構造化分析，日本建 築学会計画系論文集，第 489 号, pp.187-194，1996.11

6) 峰政，伊藤，古阪：建筑プロジェクトにおける生産情報の確定過程，日本 建築学会計画系論文集，第 502 号, pp.187-194，1997.12

7) 峰政, 服部，坂本，古阪：建築ブロジェクトにおける生産情報の共有と整 合のしくみ，日本建築学会計画系論文集，第 504 号，pp.179-186，1998.2 8) 峰政，伊藤，古阪：建築生産情報の計画的確定手法の開発と GA の適用可 能性，日本建築学会計画系論文集，第 512 号，pp. 229-236，1998.10 9) 峰政, 伊藤, 古阪 : 生産情報確定工程最適化問題への GA の適用，日本建 築学会計画系論文集，第 525 号，pp. 249-256，1999.11

10）峰政：建築プロジェクトにおける生産情報確定計画の作成支援方法に関寸 る研究, 京都大学学位論文, 1999.9

11）勝山：建築生産情報の確定過程に関する研究，京都大学修士論文，2000.2

12）田村, 水野, 手塚, 松井, 久保：離散構造とアルゴリズムIV，近代科学社

13）柳浦睦憲，茨木俊秀：組合せ最適化一メ夕戦略を中心として一，朝倉書 店, 2001

（2001年1月10日原稿受理，2001年 5 月23日採用決定） 